\title{
PERANCANGAN APLIKASI KOMPRESI FILE TEKS DENGAN MENERAPKAN ALGORTIMA FIXED LENGTH BINARY ENCODING (FLBE)
}

\author{
Rizka Dwi Pratiwi ${ }^{1}$, Surya Darma Nasution ${ }^{1}$, Fadlina ${ }^{2}$ \\ ${ }^{1}$ STMIK Budi Darma, Medan, Indonesia \\ ${ }^{2}$ AMIK STIEKOM Sumatera Utara, Rantauprapat, Indonesia
}

\begin{abstract}
Abstrak
Semakin tingginya aktivitas transaksi pertukaran data baik secara online maupun offline menimbulkan kekhawatiran terhadap beberapa pihak, Ukuran data yang besar mengakibatkan pemborosan memori dan lambatnya proses pemindahan dan pengiriman data. Untuk itu diperlukan sebuah teknik untuk mengubah ukuran data tersebut agar menjadi lebih kecil. Teknik ini disebut dengan pemampatan atau yang lebih dikenal dengan kompresi data. Kompresi data adalah suatu proses pengubahan sekumpulan data menjadi suatu bentuk kode untuk menghemat kebutuhan tempat penyimpanan data. Algoritma Fixed Length Binary Encoding (FLBE) menggunakan teknik lossless yaitu tidak menghilangkan informasi sedikitpun, hanya mewakili beberapa informasi yang sama. Hasil yang diperoleh dari penerapan algoritma Fixed Length Binary Encoding dalam proses kompresi dan dekompresi meliputi kapasitas hasil kompresi, rasio kompresi serta waktu kompresi dan dekompresi. Sesuai dengan hasil uji coba yang dilakukan terlihat bahwa data yang semula mempunyai ukuran lebih besar dapat terkompresi dengan baik diimplementasikan pada file teks.
\end{abstract}

Kata Kunci : Kompresi, File Teks, Fixed Length Binary Encoding

\begin{abstract}
The higher activity of data exchange transactions both online and offline raises concerns for some parties, large data sizes result in a waste of memory and slow data transfer and delivery processes. For this reason, a technique is needed to change the size of the data to be smaller. This technique is called compression or better known as data compression. Data compression is a process of converting a set of data into a form of code to save data storage requirements. Fixed Length Binary Encoding Algorithm (FLBE) uses a lossless technique that does not eliminate information at all, only representing some of the same information. The results obtained from the application of Fixed Length Binary Encoding algorithm in the process of compression and decompression include compression capacity, compression ratio and compression and decompression time. In accordance with the results of the experiments carried out, it can be seen that the data originally having a larger size can be compressed well implemented in text files.
\end{abstract}

Keywords: Compression, Text Files, Fixed Length Binary Encoding

\section{PENDAHULUAN}

Meningkatnya kebutuhan terhadap data digital yang semakin hari semakin tinggi, terlebih lagi saat ini internet dan telepon telah menjadi suatu kebutuhan yang sangat penting sebagai media komunikasi seperti proses pengiriman data. Akan menjadi tantangan yang cukup besar akan terbatasnya media penyimpanan (storage) dikarenakan besarnya ukuran suatu file. Pertukaran data teks baik secara online ataupun menggunakan media penyimpanan semakin besar ukuran suatu file maka membutuhkan kapasitas ruang penyimpanan yang cukup besar juga. Besarnya ukuran suatu file juga mempengaruhi pada saat proses pengiriman data melalui media transmisi yang membutuhkan waktu sangat lama untuk mengirimkan data yang memiliki ukuran yang besar tersebut.

Kebutuhan manusia modern saat ini yang banyak bekerja menggunakan komputer terlebih lagi bekerja dengan menggunakan aplikasi microsoft word, dengan mengetikkan teks. Teks ini yang akan disimpan kedalam suatu media penyimpanan berupa data yang terdiri dari karakter yang menyatukan kata-kata atau simbol inilah yang disebut dengan file teks. Kecenderungan manusia dalam mengumpulkan data berupa file teks dan dokumen yang menyebabkan manusia membutuhkakn media penyimpanan yang besar terlebih lagi saat ini manusia sering melakukan transfer file teks baik itu secara online maupun offline yang membutuhkan waktu pengiriman yang cepat.

Maka dari itu untuk menjawab tantangan tersebut dibutuhkan teknik-teknik pengolahan data, salah satu teknik pengolahan data tersebut adalah dengan kompresi data agar data hasil yang dikeluarkan dapat dimampatkan tanpa mengurangi besarnya informasi yang ada antara data sebelum dan sesudah pengolahan.

Proses Kompresi merupakan proses mereduksi ukuran suatu data untuk menghasilkan representasi digital yang padat atau mampat (compact) namun tetap dapat mewakili kuantitas informasi yang terkandung pada data tersebut [1].Secara spesifik, kompresi data bertujuan untuk mereduksi tempat (space) penyimpanan data dan mereduksi waktu untuk mentransmisikan file atau data yang memiliki kapasitas besar. Hal yang harus diperhatikan dalam kompresi data adalah time process (waktu yang berjalan pada saat data dikompresi), ratio (ukuran data 
setelah dikompresi) dan space savings (persentase selisih ukuran data setelah dikompresi dengan ukuran data sebelum dikompresi).

Berbagai algoritma telah dikembangkan untuk keperluan kompresi data. Namun, algoritma tersebut sebahagian besar lebih efisien digunakan untuk tipe data tertentu saja. Misalnya untuk kompresi text, terdapat algoritma Fixed Length Binary Encoding, Sequitur, Shannon-Fano, Burrows-Wheeler Transform (BWT), Huffman, Ziv and Lempel 77 (LZ77), Ziv and Lempel 78 (LZ78), Lempel Ziv Welch (LZW), Run Length Encoding $(R L E)$ dan lain-lain. Pada penelitian ini algoritma yang digunakan untuk mengompresi data adalah algoritma Fixed Length Binary Encoding (Flbe).

Algoritma Fixed Length Binary Encoding (FLBE) dikenal juga sebagai kode- kode blok yang mudah untuk diimplementasikan. Pada algoritma ini simbol yang asli diubah ke dalam bentuk fixed-length code yang kemudian akan mengurangi jumlah bit simbol-simbol tersebut. Kemudahan tersebut berbanding lurus dengan proses mengubah kembali fixed-length code menjadi simbol aslinya [2].

Pada penelitian sebelumnya yang dilakukan oleh Abdel-Rahman Jaradat dan Mansour I. Irshid dalam jurnal Active and Passive Elec. Comp., 2001, Vol. 24, pp. 211-221 yang berjudul "A Simple Binary Run Length Compression Technique For Non-Binary Sources Based On Source Mapping” menyatakan bahwa Kompresi akan dicapai dengan pengkodean jumlah satu diantara dua secara berturut - turut "nol" menggunakan fixed-length code atau variable-length code. Dan pada penelitian yang dilakukan oleh Wojciech Szpankowski dan Sergio Verdu dalam jurnal IEEE Transactions On Information Theory, Vol. 57, No.7, July 2011 yang berjudul "Minimum Expected Length of Fixed-to-Variable Lossless Compression Without Prefix Constraints" menyatakan bahwa teori analisis informasi, fixed-to-variable kompresi lossless, sumber tanpa memori, satu ke satu kode, Teori Shannon, sumber kode. Lossless simbol ke simbol kompresor yang diperlukan untuk memenuhi kondisi "Unique Decodability " dimana jika string input berbeda dengan hasil kompresi.

\section{TEORITIS}

\subsection{Kompresi}

Kompresi data adalah proses mengubah sebuah aliran data input menjadi aliran data baru yang memiliki ukuran lebih kecil. Aliran yang dimaksud adalah berupa file ataupun buffer dalam memori.Terdapat banyak metode untuk kompresi data. Lossy dan Lossless Compression adalah pengelompokan metode kompresi berdasarkan keutuhan data.

Lossy Compression menghilangkan beberapa data untuk memperoleh kompresi yang lebih baik, seperti Linear Predictive Coding, A-Law Algorithm, Mu-Law Algorithm, Fractal Compression, dan lain-lain. Ketika proses dekompresi dilakukan, maka output yang dihasilkan tidak sama dengan data aslinya. Metode kompresi ini lebih efektif untuk mengkompresi data gambar, video, atau audio.Sedangkan Lossless Compression tidak menghilangkan data sama sekali, sehingga cocok untuk mengkompresi data berupa teks. Yang termasuk Lossless Compression adalah Burrows-Wheeler, DEFLATE, LZW, FLBE, VLBE, Huffman, PPM, Shanon-Fano, Sequitur, dan lain-lain[8-9].

Dekompresi Data merupakan Suatu data yang sudah dikompresi tentunya harus dapat dikembalikan lagi kebentuk aslinya, prinsip ini dinamakan dekompresi [5][6][7].

\subsection{Fixed Length Binary Encoding (FLBE)}

Algoritma Fixed Length Binary Encoding (FLBE) dikenal juga sebagai kode-kode blok. Kemudahan dalam mengubah simbol yang asli ke dalam bentuk fixed-length code menjadikan algoritma ini mudah untuk diimplementasikan ke dalam software. Kemudahan tersebut berbanding lurus dengan proses mengubah kembali fixed-length code menjadi simbol aslinya [2] .

Algoritma Fixed Length Binary Encoding (FLBE) akan mengambil karakter yang terdapat dalam string yang ingin dikompresi, kemudian menghitung frekuensi (jumlah kemunculan karakter pada string). Fixed Length Binary Encoding (FLBE) mengubah bit karakter menjadi fixed-length code sehingga menghasilkan String Bit yang baru. String Bit inilah yang merupakan hasil kompresi dari algoritma Fixed Length Binary Encoding (FLBE).

\subsection{File Teks}

Teks adalah kumpulan dari karakter-karakter atau string yang menjadi satu kesatuan. File teks merupakan file yang berisi informasi-informasi dalam bentuk teks. Data yang berasal dari dokumen pengolah kata, angka yang digunakan dalam perhitungan, nama dan alamat dalam basis data merupakan contoh masukan data teks yang terdiri dari karakter, angka dan tanda baca.

Format file teks yang akan digunakan dalam penelitian ini adalah format data teks (*.txt) dan format data dokumen $(*$ doc). 


\section{ANALISA DAN PEMBAHASAN}

Adapun dalam menganalisis sistem terdapat beberapa langkah yang harus dilakukan sebagai berikut:

1. Identifikasi Masalah

Identifikasi masalah pada penelitian ini yaitu:

a. Kecenderungan mengumpulkan data dapat mengakibatkan penggunaan memori yang boros. Terutama pada File teks yang cenderung memiliki redundancy membuat penggunaan memori kurang maksimal.

b. Terdapat banyak software untuk mengkompresi data, namun belum ada yang optimal dalam melakukan kompresi berbagai tipe data.

2. Analisis Kebutuhan Sistem

Pada tahap ini terdapat kebutuhan sistem yang terdiri dari 2 jenis kebutuhan yaitu kebutuhan fungsional dan kebutuhan non-fungsional.

a. Kebutuhan fungsional

Adapun kebutuhan fungsional tersebut adalah sistem dapat membaca string yang berada dalam file teks, sistem dapat mengkompresi file teks (*.txt dan *.doc) dengan algoritma FLBE, sistem dapat mendekompresi data terhadap hasil kompresi dengan algoritma FLBE.

b. Kebutuhan non-fungsional

Beberapa kebutuhan non fungsional yang dimaksud seperti data penelitian yang akan digunakan dalam sistem, desain program, sistem operasi Windows 8 dan Microsoft Visual Basic.

3. Analisis Proses

Terdapat 2 proses utama dalam penelitian ini, yaitu proses kompresi dan proses dekompresi. Pada proses kompresi, langkah pertama yaitu mencari file teks. Misalkan terdapat file teks yang berisi string "RIZKA DWI PRATIWI".

Untuk mengetahui ukuran string, dapat dilihat pada Tabel 1.

\begin{tabular}{|c|c|c|c|c|c|}
\hline $\begin{array}{c}\text { Tar } \\
\text { akte } \\
\mathrm{r}\end{array}$ & $\begin{array}{c}\mathrm{F} \\
\mathrm{r}\end{array}$ & $\begin{array}{c}\text { ASCII } \\
\text { Dec } \\
\mathrm{k}\end{array}$ & $\begin{array}{c}\text { ASCII } \\
\text { Bin }\end{array}$ & $\begin{array}{c}\text { B } \\
\mathrm{i} \\
\mathrm{t}\end{array}$ & $\begin{array}{c}\text { Bit } \mathrm{x} \\
\text { Frek }\end{array}$ \\
\hline $\mathrm{R}$ & 2 & 82 & 01010010 & 8 & 16 \\
\hline $\mathrm{I}$ & 4 & 73 & 01001001 & 8 & 32 \\
\hline $\mathrm{Z}$ & 1 & 90 & 01011010 & 8 & 8 \\
\hline $\mathrm{K}$ & 1 & 75 & 01001011 & 8 & 8 \\
\hline $\mathrm{A}$ & 2 & 65 & 01000001 & 8 & 16 \\
\hline Sp & 2 & 32 & 00100000 & 8 & 16 \\
\hline $\mathrm{D}$ & 1 & 68 & 01000100 & 8 & 8 \\
\hline W & 2 & 87 & 01010111 & 8 & 16 \\
\hline P & 1 & 80 & 01010000 & 8 & 8 \\
\hline T & 1 & 84 & 01010100 & 8 & 8 \\
\hline
\end{tabular}

a. Proses Kompresi 
Pada algoritma FLBE, string yang telah dibaca kemudian diambil karakter yang terdapat pada string tersebut dan disusun ke dalam tabel sesuai dengan urutan kemunculan karakter pada string. Perhatikan Tabel 2 berikut ini.

Tabel 2 Total Bit Setelah Dikompresi Menggunakan Algoritma FLBE

\begin{tabular}{|c|c|c|c|c|c|c|}
\hline $\begin{array}{c}\text { Kar } \\
\text { akte } \\
\mathrm{r}\end{array}$ & $\begin{array}{c}\text { Fr } \\
\mathrm{e} \\
\mathrm{k}\end{array}$ & $\begin{array}{l}\text { Kode } \\
\text { FLBE }\end{array}$ & Bit & $\begin{array}{l}\text { Bit } x \\
\text { Frek }\end{array}$ & $\begin{array}{c}\text { Kar } \\
\text { akte } \\
\text { r }\end{array}$ & $\begin{array}{l}\mathrm{F} \\
\mathrm{r} \\
\mathrm{e} \\
\mathrm{k}\end{array}$ \\
\hline I & 4 & 0000 & 4 & 16 & $\mathrm{I}$ & 4 \\
\hline $\mathrm{R}$ & 2 & 0001 & 4 & 8 & $\mathrm{R}$ & 2 \\
\hline A & 2 & 0010 & 4 & 8 & A & 2 \\
\hline $\begin{array}{c}\text { Spa } \\
\text { si }\end{array}$ & 2 & 0011 & 4 & 8 & $\begin{array}{l}\text { Spa } \\
\text { si }\end{array}$ & 2 \\
\hline $\mathrm{W}$ & 2 & 0100 & 4 & 8 & $\mathrm{~W}$ & 2 \\
\hline $\mathrm{Z}$ & 1 & 0101 & 4 & 4 & $\mathrm{Z}$ & 1 \\
\hline K & 1 & 0110 & 4 & 4 & $\mathrm{~K}$ & 1 \\
\hline $\mathrm{D}$ & 1 & 0111 & 4 & 4 & $\mathrm{D}$ & 1 \\
\hline $\mathrm{P}$ & 1 & 1000 & 4 & 4 & $\mathrm{P}$ & 1 \\
\hline $\mathrm{T}$ & 1 & 1001 & 4 & 4 & $\mathrm{~T}$ & 1 \\
\hline \multicolumn{6}{|c|}{ Jumlah Bit x Frekuensi } & $\begin{array}{l}68 \\
\text { bit }\end{array}$ \\
\hline
\end{tabular}

Tahap selanjutnya adalah menyusun kembali kode-kode yang telah dibuat dalam tabel sesuai dengan posisi karakter pada string. Adapun string yang telah dibaca adalah:

$$
\begin{aligned}
& \begin{array}{c|c|c|c|c|c|}
\mathrm{R} & \mathrm{I} & \mathrm{Z} & \mathrm{K} & \mathrm{A} & \mathrm{sp} \\
0001 & 0000 & 0101 & 0110 & 0010 & 0011
\end{array} \\
& \begin{array}{c|c|c|c|}
\mathrm{D} & \mathrm{W} & \mathrm{I} & \text { spasi } \\
0111 & 0100 & 0000 & 0011
\end{array} \\
& \begin{array}{c|c|c|c|c|c|c}
\mathrm{P} & \mathrm{R} & \mathrm{A} & \mathrm{T} & \mathrm{I} & \mathrm{W} & \mathrm{I} \\
1000 & 0001 & 0010 & 1001 & 0000 & 0100 & 0000
\end{array}
\end{aligned}
$$

Sehingga diperoleh String Bit sebagai berikut :

0001000001010110001000110001000001010110001000111000000100101001000001000000 Sehingga total bit yang diperoleh adalah sebanyak 68 bit.

b. Proses Dekompresi

Pembacaan String Bit dilakukan dari indeks terkecil sampai indeks terakhir dengan terus menambahkan nilai pada indeks terkecil sampai indeks terakhir dengan terus menambahkan nilai pada indeks sebelumnya yang tidak terdapat pada tabel 3.2. indeks ke 0 adalah 0 , tidak terdapat dalam tabel, indeks ke 1 adalah 00 , tidak terdapat pada tabel, indeks ke 2 adalah 000, juga tidak terdapat pada tabel, indeks ke 3 adalah 0001, terdapat pada tabel bahwa 
0001 bernilai R, maka R dituliskan kedalam file, begitu seterusnya sehingga String hasil dekompresi menjadi "RIZKA DWI PRATIWI".

\section{KESIMPULAN}

Berdasarkan pembahasan dan evaluasi diatas maka dapat diambil beberapa kesimpulan sebagai berikut :

1. Pada dasarnya algoritma ini menggantikan setiap karakter dengan sebuah alternatif kode biner yang panjangnya ditentukan berdasarkan frekuensi kemunculan dari karakter tersebut. Karakter yang sering muncul akan memiliki kode biner lebih sedikit dibandingkan dengan karakter yang jarang muncul.

2. Algoritma Fixed Length Binary Encoding (FLBE) akan berhenti melakukan proses kompresi apabila panjang bit karakter mencapai jumlah karakter terakhir.

3. Algoritma Fixed Length Binary Encoding (FLBE) ini dapat menangani proses kompresi file teks dengan cukup baik.

\section{REFERENCES}

[1] D. Putra, Pengolahan Citra Digital, 1st penyunt., Yogyakarta: Andi Yogyakarta, 2010.

[2] D. Salomon dan G. Motta, Handbook of Data Compression, 5 penyunt., London: Springer, 2010

[3] J. Arifin, L. N. Zulita dan H. , "Perancangan Murottal Otomatis Menggunakan Mikrokontroller Arduino Mega 2560," Jurnal Media infotama, vol. 12, pp. 89-98, 2016.

[4] R. S. Pressman, Rekayasa Perangkat Lunak, 7 penyunt., Yogyakarta: Andi Yogyakarta, 2012.

[5] C. T. Utari, "Implementasi Algoritma Run Length Encoding untuk Perancangan Aplikasi Kompresi dan Dekompresi File Citra," Jurnal TIMES, vol. V, pp. 24-31, 2016.

[6] M. R. Irliansyah, S. D. Nasution, and K. Ulfa, "Penerapan Metode Deflate Dan Algoritma Goldbach Codes Dalam Kompresi File Teks," KOMIK (Konferensi Nas. Teknol. Inf. dan Komputer), vol. 1, no. 1, pp. 186-189, 2017.

[7] S. D. Nasution, G. L. Ginting, M. Syahrizal, and R. Rahim, "Data Security Using Vigenere Cipher and Goldbach Codes Algorithm," Int. J. Eng. Res. Technol., vol. 6, no. 1, pp. 360-363, 2017.

[8] S. D. Nasution and Mesran, "Goldbach Codes Algorithm for Text Compression," IJournals Int. J. Softw. Hardw. Res. Eng., vol. 4, no. December, pp. 43-46, 2016.

[9] T. Mizwar, G. L. Ginting, Mesran, A. Fau, S. Aripin, and D. Siregar, "IMPLEMENTASI ALGORITMA J-BIT ENCODING PADA KOMPRESI FILE TEKS,” KOMIK (Konferensi Nas. Teknol. Inf. dan Komputer), vol. 1, no. 1, pp. 232-236, 2017. 